\title{
Stem Cell Factor Measurement
}

National Cancer Institute

\section{Source}

National Cancer Institute. Stem Cell Factor Measurement. NCI Thesaurus. Code C82035.

The determination of the amount of stem cell factor present in a sample. 